\title{
Long-term effects of root plowing on vegetation in the eastern south Texas plains.
}

\author{
DONALD C. RUTHVEN III, TIMOTHY E. FULBRIGHT, SAMUEL L. BEASOM, AND \\ ERIC C. HELLGREN
}

\begin{abstract}
Authors are graduate research assistant, Caesar Kleberg Wildlife Research Institute, Texas A\&I University, Kingsville 78363; professor and chair, Department of Agronomy and Resource Sciences, Texas A\&I University, Kingsville 78363; and director and associate professor, Caesar Kleberg Wildlife Research Institute, Texas A\&I University, Kingsville 78363.
\end{abstract}

\section{Abstract}

The long-term effects of root plowing in plant communities in south Texas are not clearly understood. Our objective was to compare plant species composition and diversity on root-plowed rangelands and untreated rangelands. Two rangeland sites that were root plowed during 1973-74 and 2 sites of native, untreated brush were selected on the Santa Gertrudis Division of the King Ranch, Kleberg and Jim Wells counties, Texas. Woody plant canopy cover was estimated with the line intercept method, and density was estimated with 20-x 1-m plots during 1990. Herbaceous canopy cover was estimated with $20 \times 50-\mathrm{cm}$ quadrats. Percent grass, litter, and bare ground coverage were similar on root-plowed and untreated rangelands. Woody plant species and diversity averaged $19 \pm 2$ species/ treatment $(\bar{x} \pm$ SE) and $2.56 \pm 0.15$ on untreated areas compared to $7 \pm 1$ species/treatment and $1.18 \pm$ 0.01 on root-plowed areas. Forb canopy coverage on root-plowed sites was about twice that of untreated sites. Huisache (Acacia smallii Ilsey) canopy cover and density were both more than 7-fold greater on root-plowed sites than on untreated sites. Browse species preferred by white-tailed deer (Odocoileus virginianus Raf.), such as colima [Zanthoxylum fagara (L.) Sarg.] and guajillo (Acacia berlandieri Benth.), were absent on root-plowed sites.

Key Words: browse, brush, brush management, range improvement, wildlife habitat

Mechanical brush management became prevalent following World War II with development of heavy equipment such as the root plow in 1949 (Fisher et al. 1973), which has been used throughout the southwestern United States to manipulate woody vegetation (Allison and Rechenthin 1956, Carlton et al. 1973). Woody plants reestablish within 2 to 20 years following mechanical brush management, depending upon the type of treatment, woody plant species, and environmental conditions following treatment. In the thornscrub woodland of the western South Texas Plains, herbaceous plant diversity increased during the first 2 years following mechanical brush management (Bozzo et al. 1992). Woody plant diversity of similar communities was lower than that of the original communities 25 to 32 years following root plowing and roller chopping (Fulbright and Beasom 1987) and 7 years following repeated shredding (Fulbright 1987). Root plowing reduced the abundance of highly preferred white-tailed deer browse plants in the western South Texas Plains (Fulbright and Beasom 1987). Long-term reductions in shrub species diversity following root plowing have also been reported in the more mesic

\footnotetext{
The authors thank King Ranch, Inc., and R.H. Thompson for access and permission to conduct the study. Research was funded by Caesar Kleberg Foundation for Wildlife Conservation.

Manuscript accepted 21 Dec. 1992
}

Texas coastal prairies (Mutz et al. 1978).

There is concern among conservation and environmental groups that range management practices decrease diversity (Lewis et al. 1988). A priority for range research relevant to concerns of biological diversity is a determination of the role of human perturbations on changes in species composition of vegetation communities (McMinn 1991). Long-term changes in woody or herbaceous plant composition may be detrimental to certain wildlife species. Our objective was to determine the long-term effects of root plowing on the composition of herbaceous and woody plant communities in the eastern South Texas Plains.

\section{Materials and Methods}

The study area was on the King Ranch $\left(27^{\circ} 35^{\prime} \mathrm{N}, 98^{\circ} 0^{\prime} \mathrm{W}\right)$ in the eastern South Texas Plains (Gould 1975, Scifres 1980, Hatch et al. 1990). Climate is characterized by hot summers and mild winters with an average daily minimum winter (January) temperature of $8^{\circ} \mathrm{C}$ and an average daily maximum summer (July) temperature of $36^{\circ} \mathrm{C}$, and a growing season of about 290 days (Minzenmayer 1979, D. Largo, NAS Kingsville, pers. commun., 1992). Precipitation peaks occur in late spring (May-June) and early fall (September-October). The 30-year (1962-1991) and 10-year (1982-1991) annual precipitation averaged across the 4 study sites were $68 \mathrm{~cm}$ and $61 \mathrm{~cm}$, respectively (P. Lieck, King Ranch Inc., pers. commun. 1992). Annual precipitation during the past 10 years averaged $4 \mathrm{~cm}$ greater in the root-plowed sites.

Two separate sites, one 1,282 ha in size and one $870 \mathrm{ha}$, were root plowed during 1973-1974 (R.H. Thompson, King Ranch Inc., pers. commun., 1992). Untreated sites, one 1,140 ha and one 679 ha, consisted of undisturbed brush with small areas that were chained during 1976. Chaining in south Texas brushlands reportedly does not significantly reduce woody plant diversity (Scifres et al. 1976).

Root-plowed and untreated sites were within a 5.8-km radius of each other and were on the Czar-Delfina-Orelia soil association (State Soil Survey Staff 1977). Soils of the Czar-Delfina-Orelia association consist of loamy sands, fine sandy loams, and sandy clay loams. The study area was not mapped by soil series and the composition of each site relative to soil series was unknown (State Soil Survey Staff 1977). The Czar series are fine-loamy, mixed, hyperthermic Pachic Argiustolls; the Delfina series are fine-loamy, mixed, hyperthermic Aquic Paleustalfs; and the Orelia series are fine-loamy, mixed, hyperthermic Cumulic Haplustolls. Topography was nearly level to gently sloping and elevation ranged between 30 and $50 \mathrm{~m}$ (R.W. Schmidt, SCS, pers. commun., 1992).

Plant communities belonged to the Mesquite (Prosopis glandulosa L.)-Granjeno (Celtis pallida Torr.) association (McLendon 1991). Within this association were 2 primary communities, the 
Mesquite-Colima [Zanthoxylum fagara (L.) Sarg.]/ Granjeno community, in which colima and bluewood brasil (Condalia hookeri M.C. Johnst.) are the subdominants, and the Mesquite-Granjeno/Hog-plum [Colubrina texana (T. \& G.) Gray] community, in which hog-plum is the subdominant. Prominent herbaceous species included multi-flowered false rhodesgrass [Chloris pluriflora (Fourn.) Clayton], hooded windmillgrass (Chloris cucullata Bisch.), Texas virginsbower (Clematis drummondii T. \& G.), orange zexmenia (Wedelia hispida Jacq.) and bundle flower (Desmanthus sp. Willd.).

The study area has been grazed by domestic livestock since the 18th century (Lea 1957, Lehmann 1969). Cattle were the major form of livestock since about 1870 , whereas sheep were grazed from about 1750-1870. Recent grazing by cattle was yearlong and stocking rates, averaging 7.4 ha/ $\mathrm{AU}$, were similar for all 4 study sites during 1990 and 1991 (T.J. Haegelin, King Ranch, Inc., pers. commun. 1992).

Twenty-five transects ranging from 72 to $351 \mathrm{~m}$ long were randomly located within each study site, and four 20 -m lines were randomly placed along and perpendicular to each transect $(100 /$ site $)$. Woody plant canopy coverage was estimated during late summer and early fall 1990 by the line-intercept method (Canfield 1941). Woody plant density and frequency were estimated by counting individual plants in $10020-\times 1.5-\mathrm{m}$ plots in each site. Woody species diversity was quantified with Shannon's Index (Pielou 1975). Woody plant density and frequency were used to calculate the index. Herbaceous canopy cover was visually estimated during early fall 1990 (September-October) and early spring 1991 (March -April) in $20-\mathrm{x} 50-\mathrm{cm}$ quadrats placed at $2-\mathrm{m}$ intervals along a randomly placed line on each transect (250/site) (Daubenmire and Daubenmire 1968). Species frequency data were used to calculate Shannon's Index. Sample sizes were determined by the Stein 2staged sample test (Steel and Torrie 1980). Similarity indices were calculated with plant frequency data for both woody and herbaceous species by Motyka's version of Sorensen's similarity index (Chambers and Brown 1983). Scientific and common names of all plants are from Hatch et al. (1990).

Woody plant parameters were analyzed by a 1-way analysis of variance with treatment as the main effect (SAS Institute, Inc. 1987). Herbaceous canopy cover estimates were compared with a 2-way analysis of variance, with treatment and season as the main effects and a treatment by season interaction.

\section{Results}

Woody species, diversity, and evenness were greater on untreated areas $(19 \pm 2$ species $/$ treatment $[\bar{x} \pm \mathrm{SE}], P=0.051 ; 2.56 \pm 0.15, P=$ $0.085 ; 0.78 \pm 0.02, P=0.061$, respectively) than on root-plowed areas ( $7 \pm 1$ species/treatment, $1.18 \pm 0.01,0.61 \pm 0.04)$ (Table 1 ). Important deer browse species absent on root-plowed areas included guajillo, blackbrush (Acacia rigidula Benth.), colima, coma (Bumelia celastrina Kunth in H.B.K. LA), desert yaupon (Schaefferia cuneifolia Gray), palo verde [Parkinsonia texana (Gray) S. Wats.], and guayacan (Guiaiacum angustifolia Engelm.). Huisache comprised $10 \pm 3 \%$ of the woody plant canopy on untreated areas, compared to $72 \pm 1 \%$ of the woody canopy coverage on root-plowed areas. Mesquite $(P=0.046)$, granjeno $(P$ $=0.038$, and Texas persimmon $(P=0.057)$ canopy cover were greater on untreated areas. Huisache density was $740 \%$ greater $(P=$ 0.048 ) on root-plowed areas than on untreated areas (Table 2). Lotebush [Ziziphus obtusifolia (T.\& G.) Gray] density was greater $(P=0.079)$ on untreated areas than on root-plowed areas. Similarity indices between root-plowed sites were IS $_{\mathrm{mo}}=0.90$, between untreated sites $I S_{\mathrm{mo}}=0.65$, and between treatments $I S_{\mathrm{mo}}=0.49$.

Overall herbaceous plant canopy coverage estimates averaged $49 \pm 6 \%$ on untreated areas and $81 \pm 0 \%$ on root-plowed areas
Table 1. Woody plant canopy cover $(\%)$ of root-plowed $(n=2)$ and untreated $(n=2)$ areas on the Santa Gertrudis Division of the King Ranch, Kleberg and Jim Wells Counties, Texas, 1990.

\begin{tabular}{|c|c|c|c|c|}
\hline \multirow[b]{2}{*}{ Species } & \multicolumn{2}{|c|}{ Untreated } & \multicolumn{2}{|c|}{ Root plowed } \\
\hline & $\bar{x}$ & Range & $\bar{x}$ & Range \\
\hline & \multicolumn{2}{|c|}{$---(\%)=--$} & \multicolumn{2}{|c|}{$---(\%)---$} \\
\hline Honey mesquite & 59 & $52-67$ & 23 & $20-26$ \\
\hline Huisache & 10 & $7-13$ & 72 & $71-73$ \\
\hline Granjeno & 7 & $7-7$ & 2 & $1-3$ \\
\hline Hog-plum & 2 & $1-3$ & 3 & $2-3$ \\
\hline Texas persimmon & 4 & $3-5$ & Tr & \\
\hline Colima & 4 & 4-4 & & \\
\hline Whitebrush & 3 & $<1-5$ & & \\
\hline Bluewood brasil & 2 & $1-4$ & $<1$ & \\
\hline Blackbrush & 2 & $<1-3$ & & \\
\hline Guajillo & 1 & $0-3$ & & \\
\hline Lotebush & 1 & $1-2$ & $\mathbf{T r}$ & \\
\hline Desert yaupon & 1 & $1-1$ & & \\
\hline Paloverde & 1 & $<1-1$ & & \\
\hline Shrubby blue sage & 1 & $<1-1$ & & \\
\hline Coma & $<1$ & $<0-1$ & & \\
\hline Wolfberry & $<1$ & & $\operatorname{Tr}$ & \\
\hline Catclaw acacia & $<1$ & & & \\
\hline Twisted acacia & $<1$ & & & \\
\hline Coyotillo & $<1$ & & & \\
\hline Goatbush & $<1$ & & & \\
\hline Guayacan & $<1$ & & & \\
\hline Cedar elm & $<1$ & & & \\
\hline Texas ebony & $<1$ & & & \\
\hline Hackberry & $<1$ & & & \\
\hline Total canopy coverage & 38 & $38-38$ & 32 & $28-35$ \\
\hline
\end{tabular}

Table 2. Woody plant density (plants ha ${ }^{-1}$ ) on root-plowed $(n=2)$ and untreated $(n=2)$ areas on the Santa Gertrudis Division of the King Ranch, Kleberg and Jim Wells Counties, Texas, 1990.

\begin{tabular}{|c|c|c|c|c|}
\hline \multirow[b]{2}{*}{ Species } & \multicolumn{2}{|c|}{ Untreated } & \multicolumn{2}{|c|}{ Root plowed } \\
\hline & $\bar{x}$ & Range & $\bar{x}$ & Range \\
\hline & \multicolumn{2}{|c|}{-- (plants/ha) - - } & \multicolumn{2}{|c|}{-- (plants/ha) --} \\
\hline Honey mesquite & 285 & $250-320$ & 184 & $170-197$ \\
\hline Huisache & 82 & $43-120$ & 607 & $493-720$ \\
\hline Granjeno & 258 & $173-343$ & 100 & $83-117$ \\
\hline Hog-plum & 154 & $60-247$ & 112 & $76-147$ \\
\hline Texas persimmon & 50 & $33-67$ & 3 & $0-5$ \\
\hline Colima & 244 & $157-330$ & & \\
\hline Whitebrush & 100 & 3-197 & & \\
\hline Bluewood brasil & 45 & $13-77$ & 9 & $7-10$ \\
\hline Blackbrush & 79 & $17-140$ & & \\
\hline Guajillo & 10 & $0-20$ & & \\
\hline Lotebush & 42 & $30-53$ & 3 & $3-3$ \\
\hline Desert yaupon & 23 & $13-33$ & & \\
\hline Paloverde & 2 & $0-3$ & & \\
\hline Shrubby blue sage & 67 & $53-80$ & & \\
\hline Coma & 2 & $0-3$ & & \\
\hline Wolfberry & 7 & 7-7 & 4 & $0-7$ \\
\hline Catclaw acacia & 22 & $<1-43$ & & \\
\hline Twisted acacia & 2 & $0-3$ & & \\
\hline Coyotillo & 4 & $0-7$ & & \\
\hline Goatbush & 2 & $0-3$ & & \\
\hline Guayacan & 8 & $3-13$ & & \\
\hline Cedar elm & 1 & $0-2$ & & \\
\hline Texas ebony & $<1$ & & & \\
\hline Hackberry & 1 & $0-2$ & & \\
\hline Total density & 1,204 & $1,346-1,630$ & 1,025 & $862-1,176$ \\
\hline
\end{tabular}

(Table 3). Forb cover was significantly $(P=0.048)$ greater on root-plowed areas $(39 \pm 1 \%)$ than on untreated areas $(20 \pm 4 \%)$. Herbaceous plant richness was similar between treatments in both 
Table 3. Visual estimates of foliar cover (\%) of forbs, grass, litter, and bare ground at the Santa Gertrudis Division of the King Ranch, Kleberg and Jim Wells Counties, Texas (Fall 1990, Spring 1991), as affected by root plowing and season, $(n=2 /$ treatment/season $)$.

\begin{tabular}{|c|c|c|c|c|}
\hline & Forb & Grass & Litter & Bare ground \\
\hline Fall 1990 & \multicolumn{4}{|c|}{ 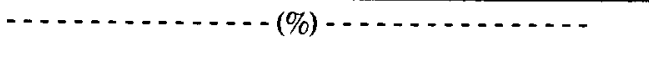 } \\
\hline Root plowed & 38 & 43 & 43 & 40 \\
\hline Untreated & 16 & 27 & 38 & 53 \\
\hline \multicolumn{5}{|l|}{ Spring 1991} \\
\hline Root plowed & 40 & 41 & 38 & 37 \\
\hline Untreated & 24 & 31 & 38 & 45 \\
\hline \multicolumn{5}{|l|}{ ANOVA P-value } \\
\hline Treatment & 0.0478 & 0.0888 & 0.6324 & 0.2267 \\
\hline Season & 0.4991 & 0.8717 & 0.5617 & 0.5340 \\
\hline $\mathrm{TRT}^{*}$ Season & 0.7294 & 0.6328 & 0.6324 & 0.7511 \\
\hline
\end{tabular}

fall and spring, with 139 and 155 species on root-plowed sites and 115 and 147 species on untreated sites. Species diversity was also similar between treatments, measuring 3.82 and 4.01 on rootplowed sites and 3.93 and 4.13 on untreated sites in spring and fall. Similarity between root-plowed sites was $I_{\mathrm{mo}}=\mathbf{0 . 6 0}$ in Fall 1990 and $I S_{m_{0}}=0.55$ in Spring 1991. Similarities between untreated sites were $I S_{\mathrm{mo}}=0.41\left(\right.$ Fall 1990) and $I S_{\mathrm{mo}}=0.52$ (Spring 1991), and between treatment indices were $\mathrm{IS}_{\mathrm{mo}}=0.42\left(\right.$ Fall 1990) and $\mathrm{IS}_{\mathrm{mo}}=$ 0.41 (Spring 1991).

Averaged across sampling dates, grass canopy cover was $45 \%$ greater on root-plowed areas (Table 3). Dominant grasses that were more frequent $(P<0.05)$ on root-plowed areas included Kleberg bluestem [Diachanthium annulatum (Forssk.) Staph.], bermudagrass [Cynodon dactylon (L.) Rich.], sandbur (Cenchrus incertus L.), threeawn (Aristida spp. L.), fall witchgrass (Digitaria cognata Fabr.), and panicum ( Panicum spp.). Although not dominant, buffelgrass (Cenchrus ciliaris $\mathrm{L}$.), which is highly rated as a pasture grass, was more frequent $(P \leq 0.0001)$ on root-plowed $(9 \pm$ $0 \%)$ than on untreated $(4 \pm 0 \%)$ areas. Hooded windmillgrass was common on both treatments.

Dominant forbs that were more frequent on root-plowed areas include croton (Croton sp.), palafoxia (Palafoxia sp.), slender verbena (Verbena officinale L.), and anemone (Anemone sp.) (Table 5). Broomweed (Xanthocephalum sp.) percent frequency was greater on untreated areas than on root-plowed areas. Forbs that were frequent in spring on both treatments included lazy daisy (Aphanostephus riddellii L.), pepperweed (Lepidium sp.), and woodsorrel (Oxalis sp.). Frequency of snoutbean (Rhyncosia

Table 4. Frequency (\%) of dominant (frequency $\geq 10 \%$ ) grasses on rootplowed $(n=4)$ and untreated $(n=4)$ areas at the Santa Gertrudis Division of the King Ranch, Kleberg and Jim Wells Counties, Texas (September-October 1990, March-April 1991).

\begin{tabular}{lccccccc}
\hline & \multicolumn{2}{c}{ Root plowed } & & \multicolumn{3}{c}{ Untreated } & \\
\cline { 2 - 3 } & $\bar{x}$ & SE & & $\bar{x}$ & SE & P-value \\
\hline Threeawn & 13 & 1 & & 4 & 2 & 0.0081 \\
Sandbur & 12 & 2 & & 2 & 1 & 0.0010 \\
Hooded wind- & 11 & 3 & 15 & 2 & 0.4263 \\
$\quad$ millgrass & & & & & \\
False rhodesgrass & 5 & 2 & & 30 & 14 & 0.1344 \\
Bermudagrass & 19 & 3 & & 4 & 2 & 0.0067 \\
Kleberg bluestem & 47 & 4 & & 12 & 3 & 0.0004 \\
Fall witchgrass & 16 & 3 & & 5 & 1 & 0.0108 \\
Lovegrass & 14 & 6 & & 5 & 2 & 0.1935 \\
Panicgrass & 12 & 2 & & 1 & 0 & 0.0472 \\
\hline
\end{tabular}

'Spring only $(n=2)$
Table 5. Frequency $(\%)$ of dominant (frequency $\geq 10 \%$ ) forbs on rootplowed $(n=4)$ and untreated $(n=4)$ areas at the Santa Gertrudis Division of the King Ranch, Kleberg and Jim Wells Counties, Texas (September-October 1990, March-April 1991).

\begin{tabular}{|c|c|c|c|c|c|}
\hline & \multicolumn{2}{|c|}{ Root plowed } & \multicolumn{2}{|c|}{ Untreated } & \multirow[b]{2}{*}{ P-value } \\
\hline & $\bar{x}$ & SE & $\bar{x}$ & SE & \\
\hline & \multicolumn{5}{|c|}{ 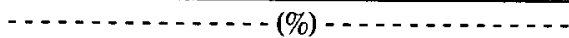 } \\
\hline Ragweed ${ }^{1}$ & 22 & 13 & 3 & 0 & 0.2830 \\
\hline Anemone & 11 & 1 & 0 & 0 & 0.0082 \\
\hline Lazy daisy? & 13 & 11 & 13 & 1 & 0.9753 \\
\hline Croton & 28 & 2 & 2 & 0 & $\leq 0.0001$ \\
\hline Tropic croton ${ }^{2}$ & 9 & 4 & 11 & 9 & 0.8254 \\
\hline Silky evolvulus & 8 & 3 & 12 & 2 & 0.3592 \\
\hline Pepperweed 1 & 43 & 8 & 20 & 1 & 0.1109 \\
\hline Woodsorrelt & 31 & 3 & 21 & 7 & 0.3273 \\
\hline Palafoxia & 15 & 1 & 3 & 2 & 0.0007 \\
\hline Plantain" & 25 & 6 & 4 & 0 & 0.0688 \\
\hline Ruellia & 11 & 5 & 12 & 3 & 0.8085 \\
\hline Slender verbena & 21 & 4 & 7 & 3 & 0.0319 \\
\hline Broomweed & 2 & 1 & 12 & 1 & 0.0007 \\
\hline
\end{tabular}

Spring only $(n=2)$

2Fall only $(n=2)$

spp.), preferred by white-tailed deer, was also greater ( $P=0.001)$ on root-plowed $(7 \pm 1 \%)$ than on untreated $(0 \%)$ areas.

\section{Discussion and Conclusions}

Huisache occurs primarily in the Texas coastal prairie and eastern South Texas Plains (Scifres et al. 1982). Based on our results and those of Mutz et al. (1978), we conclude that root plowing in these regions may result in development of a depauperate woody plant community dominated by huisache on rangeland that formerly supported a species-rich community dominated by mesquite. Twisted acacia (Acacia schaffneri $\mathrm{S}$. Wats.) increases in abundance westward into the South Texas Plains with a concomitant decrease in huisache (Mutz et al. 1978, Scifres et al. 1982). In the more arid western South Texas Plains, twisted acacia and mesquite dominate root-plowed areas (Fulbright and Beasom 1987). The long-term reductions of preferred deer browse species such as guajillo, blackbrush, colima, bluewood brasil, guayacan, coma, and desert yaupon in the eastern South Texas Plains were consistent with reports in other regions (Mutz et al. 1978, Fulbright and Beasom 1987). The changes in the woody plant community following root plowing were also similar to short-term observations in the Texas coastal prairie (Box 1964) and South Texas Plains (Davis and Winkler 1968).

The abundance of Kleberg bluestem on the root-plowed areas can be attributed to reseeding following treatment. The dominance of sandbur on the root-plowed areas may have resulted from its adaptability to invade cleared, reseeded ranges (Gould 1978). The increase of bermudagrass on the root-plowed areas relative to the untreated areas may have also resulted from its proclivity to invade disturbed areas (Gould 1975). The apparent decrease in broomweed on the root-plowed areas could be due to increased competition with grasses and other forbs. Greater canopy cover of herbaceous vegetation 16 to 18 years after root plowing was similar to the short-term observations of Drawe (1977) on the Texas coastal prairies. Double chaining and raking in south Texas (Scifres et al. 1976) and double chaining in central Texas (Rollins and Bryant 1986) also resulted in increased herbaceous coverage.

Short-term impacts of root plowing rangeland are well documented (Powell 1968, Davis and Winkler 1968, Urness 1974, Guthery et al. 1979); however, the long-term impacts of the shift from diverse thornscrub to a less diverse (woody) community on ecosystem productivity and wildlife populations are unknown and need 
further investigation. Lower browse diversity on root-plowed sites was apparently not detrimental to white-tailed deer in the eastern South Texas Plains, presumably because of great forb abundance and utilization by white-tailed deer (Ruthven 1992). However, during dry, hot summers in the western South Texas Plains, deer diets are primarily browse (Varner and Blankenship 1987). Thus, further research on the long-term effects of root plowing on whitetailed deer are needed in more xeric environments such as the western South Texas Plains where lower annual precipitation may result in low forb availability. The effects of root plowing on the diversity of the vertebrate and invertebrate communities also need to be addressed.

Appendix Table 1. Scientific names of brush, forb, and grass species.

\begin{tabular}{|c|c|}
\hline Scientific name & Common name \\
\hline $\begin{array}{l}\text { Browse } \\
\text { Acacia greggii Gray } \\
\text { Aloysia gratissima (Gill \& Hook) Troncoso } \\
\text { Diospyros texana L. } \\
\text { Castela texana Turpin } \\
\text { Celtis laevigata Willd. } \\
\text { Karwinskia humboldtiana (Schult.) Zucc. } \\
\text { Lycium carolinianum Walt. } \\
\text { Pithecellobium flexicaule (Benth.) Coult. } \\
\text { Salvia ballotiflora Benth. } \\
\text { Ulmus crassifolia } \text { L. }\end{array}$ & $\begin{array}{l}\text { Catclaw acacia } \\
\text { Whitebrush } \\
\text { Texas persimmon } \\
\text { Goatbush } \\
\text { Hackberry } \\
\text { Coyotillo } \\
\text { Wolfberry } \\
\text { Texas ebony } \\
\text { Shrubby blue sage } \\
\text { Cedar elm }\end{array}$ \\
\hline $\begin{array}{l}\text { Forbs } \\
\text { Ambrosia sp. L. } \\
\text { Aphanostephus riddellii T. \& G. } \\
\text { Croton glandulosa L. } \\
\text { Evolvulus sericeus } \mathrm{Sw} . \\
\text { Lepidium sp. } \mathrm{L} . \\
\text { Oxalis } \mathrm{sp} . \mathrm{L} . \\
\text { Plantago } \mathrm{sp} . \mathrm{L} . \\
\text { Ruellia spp. L. } \\
\text { Xanthoxylum } \mathrm{sp} .\end{array}$ & $\begin{array}{l}\text { Ragweed } \\
\text { Lazy daisy } \\
\text { Tropic croton } \\
\text { Slender evolvulus } \\
\text { Pepperweed } \\
\text { Woodsorrel } \\
\text { Plantain } \\
\text { Ruellia } \\
\text { Broomweed }\end{array}$ \\
\hline $\begin{array}{l}\text { Grasses } \\
\quad \text { Eragrostis spp. Wolf }\end{array}$ & Lovegrass \\
\hline
\end{tabular}

\section{Literature Cited}

Allison, D.V., and C.A. Rechenthin. 1956. Root plowing proved best method of brush control in south Texas. J. Range Manage. 9:130-133.

Box, T.W. 1964. Changes in wildlife habitat composition following brush control practices in south Texas. Trans. Amer. Wildl. Nat. Resour. Conf. 29:432-438.

Bozzo, J.A., S.L. Beasom, and T.E. Fulbright. 1992. Vegetation responses to brush management practices in south Texas. J. Range Manage. 45:170-175.

Canfield, R.H. 1941. Application of line interception in sampling range vegetation. J. Forest. 39:388-394.

Carlton, H.H., G.H. Abernathy, C.C. Yarbrough, and D.K. Gardner. 1973. Rootplowing and seeding arid rangelands in the southwest. J. Range Manage. 26:193-197.

Chambers, J.C., and R.W. Brown. 1983. Methods for vegetation sampling and analysis on revegetated mined lands. USDA Forest Serv. Gen. Tech. Rep. INT-151.

Daubenmire, R.F., and J.B. Daubenmire. 1968. Forest vegetation of eastern Washington and northern Idaho. Wash. Agr. Exp. Sta. Tech. Bull. 60.
Davis, R.B., and C.K. Winkler. 1968. Brush vs. cleared range as deer habitat in southern Texas. J. Range Manage. 32:321-329.

Drawe, D.L. 1977. A study of five methods of mechanical brush control in south Texas. Rangeman's J. 4:37-39.

Fisher, C.E., H.T. Wiedemann, C.H. Meadors, and J.H. Brock. 1973. Mechanical control of mesquite, p. 46-52. In: Mesquite. Res. Monogr. 1, Texas A\&M Univ., Texas Agr. Exp. Sta., College Station.

Fulbright, T.E. 1987. Effects of repeated shredding on a guajillo (Acacia berlandieri) community. Tex. J. Agr. Nat. Resour. 1:32-33.

Fulbright, T.E., and S.L. Beasom. 1987. Long-term effects of mechanical treatments on white-tailed deer browse. Wildl. Soc. Bull. 15:560-564

Gould, F.W. 1975. The grasses of Texas. Texas A\&M Univ. Press, College Station.

Gould, F.W. 1978. Common Texas grasses; an illustrated guide. Texas A\&M Univ. Press, College Station.

Guthery, F.S., T.E. Anderson, and V.W. Lehmann. 1979. Range rehabilitation enhances cotton rats in south Texas. J. Range Manage. 32:354-356.

Hatch, S.L., K.N. Gandhi, and L.E. Brown. 1990. Check list of the vascular plants of Texas. Tex. Agr. Exp. Sta. Misc. Pub. MP-1655.

Lea, T. 1957. The King Ranch. Little, Browm \& Co., Boston, Mass.

Lehmann, V.W. 1969. Forgotten legions: sheep in the Rio Grande Plain of Texas. Texas Western Press, El Paso, Tex.

Lewis, C.E., B.F. Swindel, and G.W. Tanner. 1988. Species diversity and diversity profiles: concept, measurement, and application to timber and range management. J. Range Management. 41:466-469.

McLendon, T. 1991. Preliminary description of the vegetation of south Texas exclusive of coastal saline zones. Tex. J. Sci. 43:13-32.

McMinn, J.W. 1991. Biological diversity research: an analysis. USDA Forest Serv. Gen. Tech. Rep. SE-71.

Minzenmayer, F.E. 1979. Soil survey of Jim Wells County, Texas. USDA Soil Conserv. Serv.

Mutz, J.L., C.J. Seifres, D.L. Drawe, and T.W. Box. 1978. Range vegetation after mechanical brush treatments on the coastal prairie. Texas Agr. Exp. Sta. Tech. Rep. B-1191.

Pielou, E.C. 1975. Ecological diversity. John Wiley \& Sons, N.Y.

Powell, J. 1968. Rodent numbers on different brush control treatments in south Texas. Tex. J. Sci. 20:69-76.

Rollins, D., and F.C. Bryant. 1986. Floral changes following mechanical brush removal in central Texas. J. Range Manage. 39:237-240.

Ruthven, D.C. III. 1992. Long-term effects of root plowing on white-tailed deer nutritional condition, population, status, and diet composition. M.S. Thesis. Texas A\&I Univ., Kingsville, Tex.

SAS Institute Inc. 1987. SAS user's guide: statistics, 1987 edition. SAS Institute Inc., Cary, N.C.

Scifres, C.J. 1980. Brush management, principles and practices for Texas and the Southwest. Texas A\&M Univ. Press, College Station.

Scifres, C.J., J.L. Mutz, and G.P. Durham. 1976. Range improvement following chaining of south Texas mixed brush. J. Range Manage. 29:418-421.

Scifres, C.J., J.L. Mutz, and D.L. Drawe. 1982. Ecology and management of huisache on the Texas coastal prairie. Tex. Agr. Exp. Sta. Pub. B-1408.

State Soil Survey Staff. 1977. General soil map: Kleberg County, Texas. USDA Soil Conserv. Serv. 4-R-36365.

Steel, R.G.D., and J.H. Torrie. 1980. Principles and procedures of statistics, second edition. McGraw-Hill Book Co., Inc., New York, N.Y.

Urness, P.J. 1974. Deer use changes after root plowing the Arizona chapparal. U.S. Forest Serv. Res. Note. Rm-255.

Varner, L.W., and L.H. Blankenship. 1987. Southern Texas shrubsnutritive value and utilization by herbivores, p. 108-112. In: F.D. Provenza, J.T. Flinders, and E.D. McArthur (eds.)., Proc. of Symp. On Plant-Herbivore Interactions. USDA Forest Serv. Gen. Tech. Rep. INT-222. 